\title{
BASIC METHODS OF FORMING ECOLOGICAL CONSCIOUSNESS THE PERSON
}

SOBCZYK Wiktoria, PL

NAGORNIUK Oksana - SHE Olga - TERESHCHENKO Iryna, UA

\section{Resumé}

The achievement high ecological culture of person is possible only after a regular influence on young minds by different methods of education. This is a continuous process of learning, education, training and personal development, provided forming ecological consciousness and responsibility for the improvement of the environment

Keywords: ecological education, ecological education, ecological consciousness, methods of forming ecological consciousness

\section{ОСНОВНІ МЕТОДИ ФОРМУВАННЯ ЕКОЛОГІЧНОЇ СВІДОМОСТІ ОСОБИСТОСТІ}

СОБЧИК Вікторія, Польща, НАГОРНЮК Оксана - ШЕ Ольга - ТЕРЕЩЕНКО Ірина, Україна

\begin{abstract}
Анотація.
Досягнення високої екологічної культури особистості можливе лише за умови регулярного впливу на молоду свідомість різними методами виховання. Це $\epsilon$ безперервний процес навчання, освіти, виховання i розвитку особистості, що забезпечується формуванням екологічної свідомості та відповідальності за покращення стану природного середовища.
\end{abstract}

Ключові слова: екологічна освіта, екологічне виховання, екологічна свідомість, методи формування екологічної свідомості

\section{Introduction.}

We live in a time of great disharmony between the external culture which manifests itself in the human ability to create outstanding works and internal culture, deficiency of which causes global ecological crisis. Therefore, formation of ecological culture of the population is a priority task of our time.

Ecological education and training - is a continuous process of learning, education, training and personal development. Purposeful development of the younger generation of high ecological culture aimed at forming a system of knowledge and skills, value orientations and rights, ethical and aesthetic relationships, ensuring formation of ecological consciousness and responsible for the condition and improvement of natural environment.

\section{Main part.}

For effective interaction between adults and children it is used a variety of methods to facilitate the formation of ecological culture and children's life and regulate their behavior in the environment, in particular:

- methods of forming the consciousness of personality (story, interview, lecture, example, debate, analysis of the educational situation);

- methods of life activity organization and behavior of pupils (orders, exercise, accustom, create educational situations); 
- methods of activity stimulation and behavior of pupils (demand, competition, encouragement, punishment, "blast" method of natural consequences);

- methods of self-education (reflection, the order to themselves, convinced themselves, the report themselves, approval or disapproval of themselves and others.);

- methods of control and self-control (teacher observation, interview, poll, analysis of results of the students activities, creation of control situations).

All methods have a cumulative effect on all areas of the psyche of a young man. However, each method of education is different from each other so, which is the sphere of personality it provides the dominant, and more strong directional effect.

Means of solving the crisis in relations between society and nature must be sought in same causes of its origin. Features of human activities generate the current crisis in relations between society and nature, and they create the main preconditions to avoid global ecological catastrophe. Human activity has conscious, expedient nature and its characteristics caused by specific features of consciousness. Therefore, methods of forming consciousness are the dominant.

Methods of forming ecological consciousness - a methods of influence on the intellectual sphere of personality to form opinions, concepts, attitudes, judgments, estimates related to environmental management and conservation natural environment. Their tasks are:

- knowledge of the laws of system integrity of nature and the interaction between society and nature;

- the ability to improve ways of social development and global management of natural components;

- development of new or further development of ideas, concepts and values that vary over time;

- develop the right attitude to certain actions or relationships;

- bringing moral qualities in pupils minds;

- develop skills to analyze and evaluate own actions, behavior in general (training the reflection);

- formation of adequate self-esteem.

Any information the students accept as much as it is a logical and provable. Thus they evaluate the information and adjust it. Making sure of the correctness of the foregoing, the students form a system of views on the world, society, social relations.

The effectiveness of educational methods is provided by subject to the following conditions:

- reliance on personal experience and practical collective activity;

- creating emotional support (joy, understanding, compassion, etc.);

- intensification of perception (active involvement of students in the discussion, bringing examples, selection of literary texts, participated in the staging of moral situations, etc.);

- authority of the educator.

The views received from outside and imposed by force, often generate rejection reaction or disagreement. Success is achieved when in person instead resistance manages to generate response, and to awaken its own activity. So inspiring the child certain ideas, thoughts, norms need to stop in time, do not finish the opinion to the end, don't formulate conclusions, generalizations. Launched in motion pupil thought can not stop, he ends the opinion and it becomes its own. The idea that was born from the middle, encourage to the relevant arguments and their protection. The ability to stop in time - a difficult and teacher should it form in himself all his life.

The analysis of educational situations, ways to overcome the moral contradictions that arise in various conflicts, moral problem situations have shown that every child has to build up their experience socially useful behavior and life in conditions that form the elements of moral 
orientation, highly moral installations that in further will not allow him to behave dishonorably, dishonourably.

In children useful to form the ability to opinions on the principle of equity, by the method of solving dilemmas (need to choose between two possibilities). The method of dilemmas consists in the common discussing moral behavior. To each dilemma developed question under which the discussion is based. On each issue children suggests compelling evidence "for" or "against". Analysis of the answers useful to conduct for the following criteria: choice, value, social role and justice. Each dilemma determining valuable reference points of person which should be based on relevance to real life, be simple to understand, unfinished, include two or more questions, filled with moral content, offering the choice of the students answers, focusing on the main question: "How should behave central hero? " Such dilemmas always generate controversy of the audience where everyone brings their evidence, and this makes it possible in future to make the right choices in life situations.

The method of specific compelling illustrations of the ideal built on the susceptibility of children to imitate. Based on an example worthy of imitation, the child himself can change his behavior and regulate his actions that can be called self-regulation. For example, in the literature is conventionally negative heroes. They clearly show all the behavior of children, but without teachings, notations and humiliation, but with fun and humor. Children see themselves in the mirror, do not learn to be like them.

Environmental consciousness is designed to determine the specifics of its operation in the overall structure of social consciousness. Formation of ecological consciousness in the modern era, according to many scientists, follows on four main areas:

- scientific that is expressed in an effort to put into practice the existing theoretical and practical knowledge about existing relationships in the natural world, about how to avoid violations during the human commercial activity;

- economic - expressed in the awareness the economic unprofitability of productive activity that destroys surrounding human environment;

- cultural - manifested in an effort to preserve the natural environment as part of the cultural environment;

- political - finds expression in the desire of people to create the conditions of existence, the relevant human dignity.

Knowledge of nature by human has always been one of the most important means of their active transformation according to the diverse practical needs of the individual. Environmental aspect of consciousness must perform the opposite function - to limit human intervention in natural processes beyond environmentally acceptable conditions. This is system of prohibitions and religious rules, customs and traditions of the people. As a result of this particular ecological consciousness in its completed form could not arise spontaneously. On the contrary, in its essence, it must resist the spontaneous human desire for unfettered expansion in nature and affirmation itself as social and reasonable beings. The entire previous history of mankind consisted of a constant and intense struggle for the affirmation of human in the nature world by "victory" over it. But for every such "victory" nature quite cruel "revenge", as the facts of the history of social interaction with the environment.

The special features of forming ecological consciousness should include:

1) complex character, which takes into account the object of reflection, environmentally minded person must demonstrate the ability to not only understand the relationship of certain natural phenomena and the consequences of transforming nature human activity, but also keep track of what they are relationships with other phenomena of a wider system than that seen directly;

2) the ability to include object mapping and knowledge in all its varying quality, heterogeneity and see some diversity to this essential unity, important in the ecological sense; 
3) the ability to see not only the coming consequences of changes occurring in nature, but more remote consequences, to see not only direct but also feedback changes occurring in nature and society.

If we consider the environmental consciousness by way of reflection, the most specific feature can define that which can not be limited only preliminary practices, theoretical constructs and conceptual apparatus of individual sciences, because they focus on the study of individual phenomena of nature and being of society contradicts the main task - to cover the integrity of knowledge qualitatively heterogeneous phenomena.

\section{Conclusion.}

Ecological sustainability has become a major factor in determining the safe perspective of society. It is determined by a system of sustainable, stable functioning of the biosphere with requirements to ensure optimal conditions for the preservation of the natural environment and the future of life on Earth. Public safety, maintaining created by it the material basis of life and natural habitat - one of the most important imperatives of humanity.

Today, however, continues, on the one hand, pollution and uncontrolled destruction of the biosphere on the other - a catastrophe immoral norms and values in the minds of millions of people. Nihilism and the imbalance of global ecosystems are dramatic evidence of our time.

Therefore itself the presence of ecological consciousness are not sufficient to ensure that the material prerequisites have been able to realize their potential in eliminating the global ecological crisis. The presence of certain knowledge, ideas does not guarantee appropriate behavior. Ecological behavior impossible without ecological culture and ecological responsibility.

\section{Bibliography}

1. Екологічна культура - необхідний фактор безпечної перспективи розвитку суспільства. http://social-science.com.ua/article/366

2. Методи формування свідомості. http://stud.com.ua/46469/pedagogika/metodi vihovannya\#561

3. Собчик В., Нагорнюк О. Система екологічного виховання у вищих навчальних закладах України і Польщі. - Київ: Національний аграрний університет, 2006 - с. 325-334.

4. Sobczyk W., Kiełbasa W.: Znaczenie zasad etyki i norm ochrony ekologicznej. Międzynarodowa Konferencja «Modernizace vysokoskolske vyuky technickych predmetu». Hradec Kralove, Czechy, 2005. s. 119-123.

\section{Address:}

NAGORNIUK Oksana, $\mathrm{PhD}$ in Agriculture Science (ecology), Assistant professor of Department General of Ecology and safety of activity life, National University of Life and Environmental Sciences of Ukraine, onagornuk@ukr.net

SHE Olga, the leading expert legal support of foreign citizens of Center for International Activity of National University of Life and Environmental Sciences of Ukraine, olka1990@ukr.net

TERESHCHENKO Iryna, PhD student, ira1255@ rambler.ru 